\title{
Microclimatic modifications and productive responses of the Iceberg lettuce (Lactuca sativa) in protected environments ${ }^{1}$
}

\author{
Modificações microclimáticas e respostas produtivas da alface americana em \\ ambientes protegidos
}

\author{
Rosana Fernandes Otto ${ }^{2 *}$, Priscila Cristina Niesing ${ }^{3}$, Marluce Gonçalves Cortez $^{4}$ e Ana Elise de Oliveira ${ }^{3}$
}

\begin{abstract}
Experiments were carried out in Ponta Grossa - PR, Brazil, in the winter and spring/summer periods with iceberg lettuces cultivars Lucy Brown and Raider Plus. The objectives were to assess the lettuce productive responses and the intensity of the microclimate modifications in five cropping systems as under shade nets Aluminet $40-\mathrm{O}^{\circledR}(\mathrm{AL})$ and ChromatiNet Vermelha ${ }^{\circledR} 40(\mathrm{CR})$, a low tunnel covered with transparent polyethylene (TU), direct cover white nonwoven (NW) and natural conditions (NT). A complete randomized design was used for both the experiments with five treatments placed in a $5 \times 2$ factorial arrangement (cropping systems x cultivars) and four replications. The photosynthetically active radiation and air temperature were monitored by installing probes in a datalogger system. In the winter both cultivars under NW and TU produced 21 days earlier compared to the other environments but they presented fresh commercial head similar to NT at the end of the cycle and superior to CR and AL. In the spring/summer there was no difference in the lettuce cycle regardless of the cultivar and the cropping systems. The Lucy Brown cultivar presented smaller sized heads for the winter cropping but did not differ from Raider Plus during the spring/summer. The mean air temperature of the air under NW was higher than in the other environments in both experiments. The use of the different covering materials reduced the photosynthetically active radiation available to the plant but did not prevent commercial head production of Iceberg lettuce.
\end{abstract}

Key words: Tunnel. Nonwoven. Aluminet $40-\mathrm{O}^{\circledR}$. ChromatiNet Vermelha ${ }^{\circledR} 40$. Polypropylene.

RESUMO - Foram conduzidos experimentos, em Ponta Grossa - PR, durante os períodos de inverno e primavera/verão, com alface americana (Lucy Brown e Raider Plus). Os objetivos foram avaliar as respostas produtivas da alface e a intensidade das modificações microclimáticas ocorridas em cinco ambientes de cultivo, sendo telados com Aluminet 40-O ${ }^{\circledR}$ (AL) e com ChromatiNet Vermelha ${ }^{\circledR} 40(\mathrm{CR})$, túnel baixo com polietileno transparente (TU), agrotêxtil branco direto (NW) e ambiente natural (NT). Para ambos os experimentos, o delineamento foi inteiramente casualizado com tratamentos distribuídos em esquema fatorial $5 \times 2$ (ambientes de cultivo x cultivares), com quatro repetições. A radiação fotossinteticamente ativa e a temperatura do ar foram monitoradas mediante a instalação de sensores em um sistema de aquisição de dados. No inverno, NW e TU apresentaram precocidade de 21 dias para ambas cultivares comparados aos demais ambientes, no entanto, apresentaram fitomassa fresca da cabeça comercial semelhante a NT no final do ciclo e superiores a CR e AL. Na primavera/verão não houve diferença entre o ciclo da alface, independente da cultivar e do ambiente de cultivo. A cultivar a Lucy Brown apresentou cabeças de menor tamanho para o cultivo de inverno, não diferindo da Raider Plus durante a primavera/verão. A temperatura média do ar sob NW foi superior aos demais ambientes para ambas as épocas de plantio. $\mathrm{O}$ uso dos diferentes materiais de cobertura reduziu a radiação fotossinteticamente ativa disponível para as plantas, mas não impediu a produção de cabeça comercial de alface americana.

Palavras-chave: Túnel. Agrotêxtil. Aluminet 40-O ${ }^{\circledR}$. ChromatiNet Vermelha ${ }^{\circledR} 40$. Polipropileno.

\footnotetext{
*Autor para correspondência

Recebido para publicação em 26/10/2011; aprovado em 28/05/2013

Parte da Dissertação de Mestrado do segundo autor apresentada ao Programa de Pós-Graduação em Agronomia da Universidade Estadual de Ponta Grossa/UEPG

${ }^{2}$ Departamento de Fitotecnia e Fitossanidade/DEFITO/UEPG, Av. Carlos Cavalcanti 4748, Uvaranas, Ponta Grossa-PR, Brasil, 84.030-900, rfotto@uepg.br

${ }^{3}$ Engenheiras Agronômas, Universidade Estadual de Ponta Grossa, Ponta Grossa-PR, Brasil, priniesing @yahoo.com, aeoliveira@ig.com.br

${ }^{4}$ Departamento Fitotecnia e Fitossanidade/DEFITO/UEPG, Av. Carlos Cavalcanti 4748, Uvaranas, Ponta Grossa-PR, Brasil, mgcortez@ uepg.com.br
} 


\section{INTRODUCTION}

Lettuce is the most popular leafy vegetable in Brazil with an annual production of 800,000 tons and yield of 20 to $25 \mathrm{t} \mathrm{ha}^{-1}$ (PANORAMA, 2010). The summer crisp type lettuce is the most consumed but the Iceberg type has increased its market participation especially in the fast food chains.

Lettuce is produced all year round because of the different types and cultivars released on the market. However, the Iceberg type presents limitations for cropping in some regions and seasons. Most of the cultivars are suitable for planting in mild/cool temperatures that do not occur in a great part of Brazil, especially in the spring/summer period. In addition to the physiological requirements of the plant for climatic conditions, excess rain during warm periods contributes to the development of diseases that reduce quality and yield.

The alternatives would be releasing cultivars adapted to high temperatures with greater disease resistance and cropping in protected environments that would more suitable to the physiological requirements of the plant. Plastic greenhouses are the most well-known structures, but they are more used for lettuce cropping in the hydroponic system.

Low plastic tunnels are easily managed structures than greenhouses and also reduce excess moisture on the plant in the period of greatest rainfall. The use of the tunnel has shown positive results for earliness and yield increase (SÁ; REGHIN, 2008; STRECK et al., 2007), even when perforated plastic (MONTEIRO, SILVA, PIEDADE, 2002) or different materials (BARROS JÚNIOR et al., 2004; STRECK et al., 2007) were used over the structure.

Nonwoven would be another protective cropping system that is placed directly over the plants modifying radiation, air and soil temperature (GIMENEZ; OTTO; CASTILHA, 2002; OTTO et al., 2001a; PEREIRA; OTTO; REGHIN, 2003; SÁ; REGHIN, 2008). It has the advantages of earliness and increased productivity (FELTRIM et al., 2008; OTTO; REGHIN; SÁ, 2001b; OTTO et al., 2010; SALAS et al., 2008) and improved quality of the commercial product (OTTO et al., 2010).

Shade nets are another materials used in crop protection and can be used under plastic in greenhouses, in low or high tunnels or supported by stakes more than 2 $\mathrm{m}$ tall. The netting modify the light spectrum resulting in increased diffuse light that can reach the lower-positioned leaves of the plant and contribute to the photosynthesis process (LEITE et al., 2011). The effects of high temperature and luminosity can be minimized significantly when these types of netting are used.

The choice of plant protection systems depends on the adverse condition that limits the crop production and the main factor is solar radiation followed by air temperature. The level of available radiation for most vegetables is approximately $8.4 \mathrm{MJ} \mathrm{m}^{-2} \mathrm{day}^{-1}$, considering the minimum value necessary for their maintenance (FOOD AND AGRICULTURE ORGANIZATION, 1990). The point of luminous saturation for cultivated C3 plants, such as lettuce, is 1000 to $1500 \mu \mathrm{mol}$ photons $\mathrm{m}^{-2} \mathrm{~s}$ ${ }^{1}$ (HE; LEE; DODD, 2001; LARCHER, 2004). According to Wurr and Fellows (1991), the Iceberg lettuce phytomass is positively related to solar radiation and negatively correlated with temperature during the head formation process, but these responses also vary with the cultivar.

The objective of the present study was to assess the productive responses of Iceberg lettuce cropped in four protected environments and the natural conditions, monitoring the microclimatic modifications during the crop cycle in the winter and spring/summer periods in the region of Ponta Grossa, PR, Brazil.

\section{MATERIAL AND METHODS}

The experiments were carried out in Ponta Grossa, PR, Brazil (2505'39” S, 50 03'34” W, 950 m mean altitude), during the winter (01/06/2005 to $28 / 07 / 2005)$ and the spring/summer (12/10/2005 to $14 / 01 / 2006)$. The relief is classified as plane and the mean altitude is $900 \mathrm{~m}$. The soil in the experimental area is clay textured dystrophic haplic cambisol.

A complete randomized design was used for both experiments distributed in a $5 \times 2$ factorial scheme: cropping systems [natural environment, low tunnel with polyethylene (100 micras), white nonwoven $\left(20 \mathrm{~g} \mathrm{~m}^{-2}\right)$, screens with thermo reflectors net (Aluminet 40-O ${ }^{\circledR}$ $40 \%$ ) and diffuser net (ChromatiNet Vermelha ${ }^{\circledR} 40$ )] and two lettuce cultivars (Raider Plus and Lucy Brown), with four replications. The area of the experimental plot was $6.0 \mathrm{~m} \mathrm{x} 1.2 \mathrm{~m}$ with $0.30 \mathrm{~m}$ between plant spacing. The useful area was defined as the two central rows and the plants at the ends of each row were discarded.

The experimental area was fertilized by hand with $160 \mathrm{~g} \mathrm{~m}^{-2}$ of the NPK (05-25-10) formula. After incorporating the fertilizer in the soil two fertirrigation lines were installed in the bed, with nozzles spaced at $0.30 \mathrm{~m}$ and $1.5 \mathrm{~L} \mathrm{~h}^{-1}$ flow. The bed was then covered with black nonwoven mulching $\left(40 \mathrm{~g} \mathrm{~m}^{-2}\right)$ to prevent weed growth and to prevent the plant leaves coming into contact with the soil.

The seedlings were produced in a greenhouse covered with polyethylene, sown on polystyrene trays with 128 cells containing commercial coconut fiber substrate. The cultivars in experiment 1 (winter) were sown on $01 / 06 / 05$ and transplanted 34 days after sowing 
(DAS) and for experiment 2 (spring/summer) sowing was on $12 / 10 / 05$ and transplant at 36 DAS.

After transplanting, the treatments were set up corresponding to each cropping environment. The nonwoven was placed directly over the plants and secured at the edges with iron pegs. The low tunnel was $1.2 \mathrm{~m}$ width and $1.0 \mathrm{~m}$ high at the center of the arch. The closed nettings had $2.0 \mathrm{~m}$ tall wooden structures on the four edges and crossed wires between the stakes. Thermo reflectors net (Aluminet 40-O ${ }^{\circledR} 40 \%$ ) and diffuser net (ChromatiNet Vermelha ${ }^{\circledR} 40$ ) were placed on structures for each corresponding treatment.

Plant health was controlled with procimidone (120 $\mathrm{g} \mathrm{ha}^{-1}$ ) for white mold (Sclerotinia sclerotiorum), applied weekly after the disease was identified and pirimicarb $\left(1 \mathrm{~g} \mathrm{~L}^{-1}\right)$ to control sucking insects.

For the winter experiment, the commercial head was harvested 65 days after transplant (DAT) for the crops under the plastic tunnel (TU) and nonwoven (NW) and at 86 DAT for the other environments. For the spring/ summer experiment, the final harvest was at 58 DAT for all the treatments. The characteristics assessed were total fresh (TFP) and dry phytomasses (TDP), fresh (FCH) and dry commercial head (DCH).

In both the experiments the photosynthetically active radiation (PAR) and the air temperature $(20 \mathrm{~cm}$ above ground level) were monitored for all the cropping systems. The LI190SB sensor (LICOR Quantum Sensor) was used to measure PAR, level with the soil surface and a thermocouple (107 Temperature sensor - Campbell Sci.) was used to measure the temperature. The sensors were connected to a datalogger system (CR23x, Campbell Sci.) programmed to take temporary measurements every minute, storing the hourly means during the Iceberg lettuce cycle.

The variances in the treatments were tested for homogeneity by the Bartlett test. The data were submitted to the analysis of variance and the means compared by the Tukey test at the level of $5 \%$.

\section{RESULTS AND DISCUSSION}

There was no interaction in experiment 1 (winter) among cultivars and cropping systems for total fresh (TFP) and dry phytomasses (TDP), fresh (FCH) and dry commercial head (DCH) of the Iceberg lettuce cultivars (Table 1).

For cropping systems, the plants growing in the natural conditions (NT), under nonwoven (NW) and under the plastic tunnel (TU) presented similar TFP and $\mathrm{FCH}$ but were superior to those produced under the Aluminet 40-O ${ }^{\circledR}(\mathrm{AL})$ and $\mathrm{CromatiNet}^{\circledR}(\mathrm{CR})$ nets (Table 2). However, the differences among the cropping systems did not continue when TDP and DCH were compared (Table 2). The results were related to the characteristics of the plot protection materials.

Table 1 - Summary of analysis of variance of Total fresh phytomass (TFP), fresh commercial head (FCH), total dry phytomass (TDP) and dry commercial head (DCH) of lettuce cultivars (Cv) cropped a in a different environments (Env) to winter and spring/summer experiments. Ponta Grossa, PR. 2005

\begin{tabular}{|c|c|c|c|c|c|}
\hline \multirow{3}{*}{ Source } & \multirow{3}{*}{$\mathrm{DF}$} & \multicolumn{4}{|c|}{ Mean Square } \\
\hline & & \multicolumn{4}{|c|}{ winter } \\
\hline & & TFP & $\mathrm{FCH}$ & TDP & $\mathrm{DCH}$ \\
\hline Env & 4 & $6919457,8 * *$ & $4189405,7 * *$ & $2919,8 * *$ & $823,8^{\mathrm{ns}}$ \\
\hline $\mathrm{Cv}$ & 1 & $19871131,2 * *$ & $10071126,0^{* *}$ & $30288,5^{* *}$ & $10725,6^{* *}$ \\
\hline $\mathrm{Env}^{*} \mathrm{Cv}$ & 4 & $43124,2^{\mathrm{ns}}$ & $339867,5^{\mathrm{ns}}$ & $379,9^{\mathrm{ns}}$ & $680,1^{\mathrm{ns}}$ \\
\hline Error & 30 & 581312,3 & 339626,4 & 713,6 & 342,5 \\
\hline \multirow[t]{2}{*}{$\mathrm{CV}^{1}$} & & $\overline{17,3}$ & 18,3 & $\overline{17}, 6$ & 20,9 \\
\hline & & \multicolumn{4}{|c|}{ spring/summer } \\
\hline Env & 4 & $1998642,7^{\mathrm{ns}}$ & $2396704,6^{*}$ & $353,8^{\mathrm{ns}}$ & $423,5^{\mathrm{ns}}$ \\
\hline $\mathrm{Cv}$ & 1 & $1996423,0^{\mathrm{ns}}$ & $799809,3^{\text {ns }}$ & $4642,9^{\mathrm{ns}}$ & $2548,7^{\mathrm{ns}}$ \\
\hline Env*Cv & 4 & $698750,9^{\text {ns }}$ & $438184,1^{\mathrm{ns}}$ & $208,9^{\mathrm{ns}}$ & $60,8^{\mathrm{ns}}$ \\
\hline Error & 30 & 1023583,7 & 703410,9 & 1766,3 & 833,3 \\
\hline $\mathrm{CV}^{1}$ & & $\overline{16,9}$ & $\overline{17}, 0$ & 21,7 & $\overline{25}, 7$ \\
\hline
\end{tabular}


Table 2 - Total fresh phytomass (TFP), fresh commercial head (FCH), total dry phytomass (TDP) and dry commercial head (DCH) of the Raider Plus (RP) and Lucy Brown (LB) lettuce cultivars cropped a in natural conditions (NT), under nonwoven (NW), plastic tunnel (TU), shade nets Aluminet 40-O® (AL) and ChromatiNet Vermelha® 40 (CR). Ponta Grossa, PR. 2005

\begin{tabular}{|c|c|c|c|c|c|c|c|c|}
\hline \multirow{3}{*}{ Environment } & \multicolumn{4}{|c|}{ winter } & \multicolumn{4}{|c|}{ spring/summer } \\
\hline & TFP & $\mathrm{FCH}$ & TDP & DCH & TFP & FCH & TDP & DCH \\
\hline & \multicolumn{4}{|c|}{$-{ }^{-1}$} & \multicolumn{4}{|c|}{ - } \\
\hline NT & 4928 a1 & $3708 \mathrm{a}$ & $179,7 \mathrm{a}$ & $102,2 \mathrm{a}$ & $6302 \mathrm{a}$ & $5263 \mathrm{ab}$ & $191,6 \mathrm{a}$ & $112,1 \mathrm{a}$ \\
\hline NW & 5209 a & $3821 \mathrm{a}$ & $140,6 \mathrm{a}$ & $82,7 \mathrm{a}$ & $6883 \mathrm{a}$ & 5665 a & 198,4 a & $111,9 \mathrm{a}$ \\
\hline $\mathrm{TU}$ & $5078 \mathrm{a}$ & $3557 \mathrm{a}$ & $171,1 \mathrm{a}$ & $95,8 \mathrm{a}$ & $5654 \mathrm{a}$ & $4485 \mathrm{ab}$ & $202,2 \mathrm{a}$ & $125,7 \mathrm{a}$ \\
\hline $\mathrm{AL}$ & $3600 \mathrm{~b}$ & $2594 \mathrm{~b}$ & $142,2 \mathrm{a}$ & $79,3 \mathrm{a}$ & $5901 \mathrm{a}$ & $4867 \mathrm{ab}$ & $186,2 \mathrm{a}$ & $116,9 \mathrm{a}$ \\
\hline $\mathrm{CR}$ & $3205 \mathrm{~b}$ & $2221 \mathrm{~b}$ & $147,1 \mathrm{a}$ & $81,3 \mathrm{a}$ & $5523 \mathrm{a}$ & $4392 \mathrm{~b}$ & $189,1 \mathrm{a}$ & $106,2 \mathrm{a}$ \\
\hline \multicolumn{9}{|l|}{ Cultivar } \\
\hline $\mathrm{RP}$ & $5109 \mathrm{a}$ & $3682 a$ & $182,9 \mathrm{a}$ & $104,6 \mathrm{a}$ & $5857 \mathrm{a}$ & $4784 \mathrm{a}$ & $182,7 \mathrm{a}$ & $106,6 \mathrm{a}$ \\
\hline LB & $3699 \mathrm{~b}$ & $2678 \mathrm{~b}$ & $129,4 \mathrm{~b}$ & $71,7 \mathrm{~b}$ & $6248 \mathrm{a}$ & $5085 \mathrm{a}$ & $204,3 \mathrm{a}$ & $122,5 \mathrm{a}$ \\
\hline
\end{tabular}

${ }^{1}$ Means followed by the same letter in the column for each factor do not differ significantly by the Tukey test at $5 \%$ significance

Over the cycle, the PAR values under AL and CR were always lower than under TU, NW and NT (Figure 1A), remaining below $4 \mathrm{MJ} \mathrm{m}^{-2} \mathrm{day}^{-1}$ for most of the days of the cropping period. However, the thermal differences (Figure 1B) found among the NT, CR and AL environments and those protected with TU and NW were not as great as the differences found for the PAR values (Figure 1A) among the environments.

The characteristics of the thread that formed the ChromatiNet $^{\circledR}$ and Aluminet $40-\mathrm{O}^{\otimes}$ netting resulted in increased diffuse radiation and prevented night heat losses, contributing so that the energy balance was modified compared to the conditions of the natural conditions and other protection materials. The phytotechnical results presented by the colored shade nets are due to the alteration on the spectrum proportionate by them, and neither due to the differences in the total amount of radiation transmitted itself, either global or photosynthetically active, nor to the differences in thermic transmissivities (LEITE et al., 2011).

Hora (2006) reported that the relation between the global and PAR radiations in NT was approximately $42 \%$, according to the estimation of the equation $\mathrm{y}$ $=0.3897 \mathrm{x}+0.3183$, where $\mathrm{y}=$ PAR and $\mathrm{x}=$ global radiation. Thus most of the cultivated plants, when submitted to values less than $3.6 \mathrm{MJ} \mathrm{m}^{-2}$ day $^{-1}$ PAR radiation, would be submitted to radiation values lower than the minimum necessary for their maintenance which is $8.4 \mathrm{MJ} \mathrm{m}^{-2} \mathrm{day}^{-1}$ (FOOD AND AGRICULTURE ORGANIZATION, 1990).
Figure 1 - Incident photosynthetically active radiation [A] and mean daily air temperatures [B] during the cycle of Raider Plus and Lucy Brown Iceberg lettuces cropped in natural conditions (NT) and under nonwoven (NW), low tunnel (TU), shade nets Aluminet 40-O® (AL) and ChromatiNet Vermelha® 40 (CR) in the winter. UEPG, Ponta Grossa, PR, 2005
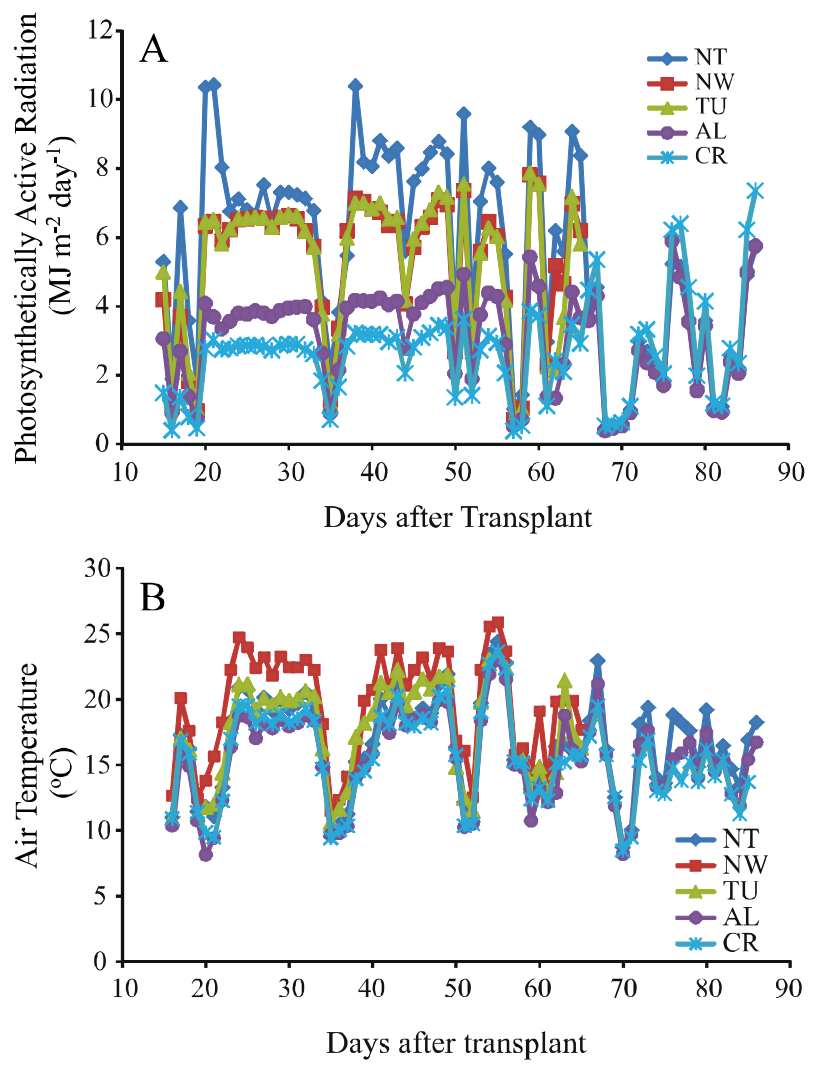
In experiment 1 (winter), the Iceberg lettuce cultivated under CR and AL were under lower radiation conditions (Figure 1A) than the minimum necessary for their maintenance, that was reflected in the lower values found for TFP and FCH compared to the other treatments (Table 2).

However, plants cultivated under $\mathrm{CR}$ and $\mathrm{AL}$ maintained carbon fixing, resulting in similar dry phytomass values compared to the plants cropped in NT, TU and NW. This result may be related to the characteristics of the ChromatiNet $^{\circledR}$ and Aluminet $40-\mathrm{O}^{\circledast}$ nets that in addition to altering the incident radiation values, modified the light spectrum, resulting in an increase in diffuse radiation in the protected environment (LEITE et al., 2011). Diffuse radiation can reach shaded plant leaves and increase photosynthesis, carbon fixing and possibly morphological alteration of the plant cells because of the alteration in the hormone balance.

Even though the $\mathrm{FCH}$ results were similar for NW, TU and NT and the DCH were similar among all the environments (Table 2), the plants cropped under NW and TU were harvested 21 days earlier than those produced in NT and under AL and CR.

This result was due to the more suitable heat management for the plants cultivated under NW and TU compared to the other environments, which favored the plant metabolism and reduced the crop cycle. The air temperature means for NT, NW, TU, AL and CR were $16.6,19.5,17.5,15.5$ and 15.5 , respectively, over the cropping cycle.

For cultivars, Raider Plus presented greater TFP and FCH than the Lucy Brown. The relationship between TDP and DCH was maintained between the cultivars (Table 2). The Raider Plus cultivar was indicated for cropping in locations with lower air temperatures than those recommended for the Lucy Brown cultivar, a climate condition that existed during experiment 1 (winter).

Results comparing cropping in NT and under NW for lettuce have shown that production under NW is greater than NT for Crisp lettuce (FELTRIM; REGHIN; VINNE, 2003; OTTO; REGHIN; SÁ, 2001b; OTTO et al., 2010) and Iceberg type (OTTO; REGHIN; SÁ, 2001b), however, a negative effect was found for butterhead type lettuce when the nonwoven weight was greater than $17 \mathrm{~g} \mathrm{~m}^{-2}$ (OTTO; REGHIN; SÁ, 2001b). Otto et al. (2001b) reported that production under NW was greater than under NT for the Iceberg lettuce cultivar Tainá, possibly because they were a different cultivar of those used in this present experiment. For AL and CR nets, Aquino et al. (2007) found that the canopy dry matters of the lettuce cultivars Regina (butterhead) and Verônica (crisp type) were less than the plants cultivated under NT, because the radiation was restricted by nettings.

Although FCH produced under AL and CR were lower than those produced in NT, NW and TU (Table 2), they were classified commercially in classes 25 (263g) and $20(200 \mathrm{~g})$, respectively, according to the Hortibrasil (2009).

For experiment 2 (spring/summer), cultivars and cropping systems interaction was not significant for TFP, FCH, TDP and DCH (Table 1). There was also no difference among Raider Plus and Lucy Brown cultivars for any of the characteristics, unlike the winter cropping (Table 2). For the spring/summer, the $\mathrm{FCH}$ presented 30\% (Raider Plus) and 90\% (Lucy Brown) increases compared to the $\mathrm{FCH}$ obtained during the winter (Table 2).

This result was related to the favorable thermal condition for lettuce cropping, especially for Lucy Brown cultivar. In the spring/summer cycle, the air temperatures were on average $6{ }^{\circ} \mathrm{C}$ higher than those found in the winter cropping period (Figure 2B). This difference was consequence of the incident radiation levels in the environments in both the periods, where the values in NT were $56 \%$ greater in the spring/summer (Figure 2A) compared to the winter (Figure 1A).

When the Lucy Brown and Raider Plus cultivars were compared, the $\mathrm{FCH}$ classification obtained was in the classes $45(458 \mathrm{~g})$ and 40 (431g), respectively, according to the HortiBrasil (2009).

However, in the different cropping systems, the FCH under CR (class 35) was smaller than NW (class 50) but did not differ from the $\mathrm{FCH}$ produced in the other environments.

In the spring/summer, the mean values detected for the PAR radiation over the cycle were upper to 3.6 $\mathrm{MJ} \mathrm{m}^{-2}$ day $^{-1}$ (Figure 2A), appropriate for the plant to produce the minimum of photoassimilates necessary for its maintenance, as described previously.

The mean air temperature under NW was greater $\left(26.2{ }^{\circ} \mathrm{C}\right)$ compared to the other cropping environments, followed by $\mathrm{TU}\left(23.9{ }^{\circ} \mathrm{C}\right)$ and $\mathrm{NT}\left(22.8{ }^{\circ} \mathrm{C}\right)$ that was similar $\mathrm{CR}\left(22.8{ }^{\circ} \mathrm{C}\right)$. $\mathrm{AL}$ had the lowest mean temperatures $\left(21.9^{\circ} \mathrm{C}\right)$ among the cropping systems (Figure 2B). 
Figure 2 - Incident photosynthetically active radiation [A] and mean daily air temperatures [B] during the cycle of Raider Plus and Lucy Brown Iceberg lettuces cropped in natural conditions (NT) and under nonwoven (NW), low tunnel (TU), Aluminet 40-O® (AL) and ChromatiNet Vermelha ${ }^{\circledR} 40(\mathrm{CR})$ nets in the spring/summer. UEPG, Ponta Grossa, PR, 2005
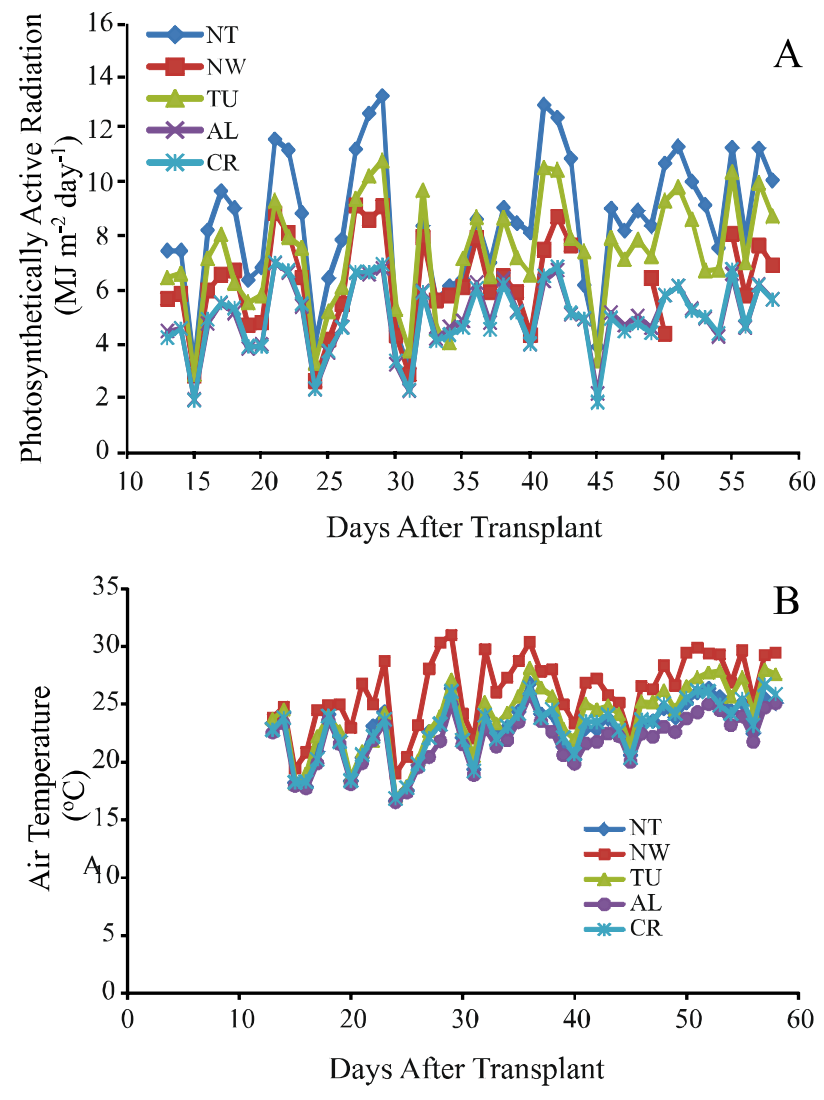

\section{CONCLUSIONS}

1.The use of the different covering materials reduced the photosynthetically active radiation available to the plant but did not prevent commercial head production of Iceberg lettuce. The Raider Plus and Lucy Brown cultivars had a better commercial classification in the spring/summer than winter period;

2.In the winter, the plants cultivated under Aluminet $40-\mathrm{O}^{\circledR}$ e de ChromatiNet Vermelha ${ }^{\circledR} 40$ produced commercial head fresh phytomass lower than that produced in natural conditions, under nonwoven and plastic tunnel. During the spring/summer, the yield under ChromatiNet Vermelha ${ }^{\circledR} 40$ was lower than that produced in NW;

3. The use of ChromatiNet, even though it increased diffuse radiation available to the plants, contributed to a microclimate less appropriate than the others environments for production of heads with better commercial classification;

4. Productions under nonwoven and plastic tunnel were 21 days earlier that in the other environments in winter period.

\section{ACKNOWLEDGMENTS}

The authors would like to thank the companies Fitesa, Seminis and Polysack for supplied part of research materials.

\section{REFERENCES}

AQUINO, L. A. et al. Produção de biomassa, acúmulo de nitrato, teores e exportação de macronutrientes da alface sob sombreamento. Horticultura Brasileira, v. 25, n. 3, p. 381-386, 2007.

BARROS JÚNIOR, A. P. et al. Cultivo da alface em túneis baixos de agrotêxtil. Horticultura Brasileira, v. 22, n. 4, p. 801-803, 2004.

FOOD AND AGRICULTURE ORGANIZATION. Protected cultivation in the Mediterranean climate. Rome: FAO, 1990. 313 p. (FAO Plant Production and Protection Paper, 90).

FELTRIM, A. L.; REGHIN, M. Y.; VINNE, J. van der. Cultivo da alface com agrotêxtil em diferentes períodos. Publicatio, Ciências Exatas Terra 9: 21-27. 2003.

FELTRIMA.L. et al. Crescimento e acúmulo de macronutrientes em chicória coberta e não coberta com polipropileno. Horticultura Brasileira, v. 26, n. 1, p. 50-55, 2008.

GIMENEZ, C.; OTTO, R. F.; CASTILLA, N. Productivity of leaf and root vegetables crops under direct cover. Scientia Horticulturae, v. 94, n. 1/2, p. 1-11, 2002.

HE, J.; LEE, S. K.; DODD, I. C. Limitations to photosynthesis of lettuce grown under tropical conditions: alleviation by root-zone cooling. Journal of experimental Botany, v. 52, n. 359, p. 1323-1330, 2001.

HORA, R. C. da. Avaliação de pepineiro enxertado em diferentes ambientes. 2006. $69 \mathrm{f}$. Tese (Doutorado em Agronomia) - Universidade Estadual Paulista, Botucatu, 2006.

LARCHER, W. Ecofisiologia Vegetal. São Carlos, 2004. 531 p.

LEITE, C. A. et al. Light spectrum management using colored nets aiming to controlling the growth and the blooming of Phalaenopsis sp. Available in: <http://www. polysack.com/files/e9f9f2aca300c62ae62d46141f287901. pdf>. Accessed: 17 ago. 2011.

MONTEIRO, J. E. B. A.; SILVA, I. J. O. da; PIEDADE, S. M. Filme plástico perfurado em túneis baixos cultivados com alface. Revista Brasileira de Engenharia Agrícola e Ambiental, v. 6, n. 3, p. 535-538, 2002. 
OTTO, R. F. et al. Modification of the thermal regime of soil-plant systems under nonwoven polypropylene and external conditions. Journal of Horticultural Science \& Biotecnology, v. 76, n. 2, p. 216-223, 2001a.

OTTO, R. F.; REGHIN, M. Y.; SÁ, G. D. Utilização do 'não tecido' de polipropileno com proteção da cultura de alface durante o inverno de Ponta Grossa - PR. Horticultura Brasileira, v. 19, n. 1, p. 49-52, 2001b.

OTTO, R. F. et al. Respostas produtivas de alface em cultivo protegido com agrotêxtil. Bragantia, v. 69, n. 4, p. 855-860, 2010 .

PEREIRA, A. V.; OTTO, R. F.; REGHIN, M. Y. Respostas do feijão-vagem cultivado sob proteção com agrotêxtil em duas densidades de plantas. Horticultura Brasileira, v. 21, n. 3, p. 564-569, 2003.

HORTIBRASIL. Classificação da alface. 2009. Disponível em http://www.hortibrasil.org.br/classificacao/alface/arquivos/ classes.html>. Acesso em 12 de set. 2011.
PANORAMA da cultura da alface no Brasil. Revista Campo \& Negócio HF, ano 5, n. 56, 2010. Available in: <http://www. revistacampoenegocios.com.br/anteriores/10-01/index.php? refe rencia=reportagemesp01>. Accessed: 24 de jun. 2010.

SÁ, G. D. de; REGHIN, M. Y. Desempenho de duas cultivares de chicória em três ambientes de cultivo. Ciência e Agrotecnologia, v. 32 , n. 2 , p. $378-384,2008$.

SALAS, F. J. S. et al. Evaluación del cultivo protegido por agrotextil en la cultura de lechuga y su desempeño en diferentes tipos de aplicaciones. Arquivos Instituto Biológico, v. 75, n. 4, p. 437-442, 2008.

STRECK, L. et al. Sistema de produção de alface em ambiente parcialmente modificado por túneis baixos. Ciência Rural, v. 37, n. 3, p. 667-675, 2007.

WURR, D. C. E.; FELLOWS, J. R. The influence of solar radiation and temperature on the head weight of crisp lettuce. The Journal of Horticultural Science \& Biotechnology, v. 66, n. 2, p. 183-190, 1991. 